\title{
STUDI SEMIOTIKA KARAKTER MONOKUMA PADA ANIME FRANCHISE SERIES "DANGANRONPA"
}

\author{
Daniel Kurniawan Salamoon \\ Fakultas Seni dan Desain, Program Studi Desain Komunikasi Visual, \\ Universitas Kristen Petra \\ daniel.kurniawan@petra.ac.id
}

\begin{abstract}
Abstrak
Penelitian ini dibuat untuk membahas tentang tokoh utama dalam salah satu anime franchise series yang laris yaitu Danganronpa. Danganronpa menceritakan kisah tentang beberapa pelajar yang terjebak di sekolah. Untuk bisa keluar dari sekolah tersebut mereka harus membunuh tanpa ketahuan. Dalam Danganronpa, tokoh yang menjadi pusat penelitian disini adalah karakter Monokuma. Monokuma merupakan kepala sekolah disana yang berwujud beruang. Studi ini membahas tentang studi desain karakter dalam perannya pada sebuah cerita. Teori yang digunakan untuk membedah ini adalah teori semiotika dimana akan dianalisis tentang elemen-elemen pembentuk desain karakter Monokuma dan peran yang ditunjukkan. Studi ini membahas bagaimana perkembangan dunia visual dalam menciptakan pemaknaan pada benak penonton.
\end{abstract}

Kata kunci : anime, Danganronpa, desain karakter, Monokuma, semiotika

\begin{abstract}
This research was made to discuss the main character in one of the best-selling anime franchise series, Danganronpa. Danganronpa tells the story of some students trapped in the school. To be able to get out of school they have to kill without getting caught. In Danganronpa, the character who is the center of research here is the character of Monokuma. Monokuma is the headmaster of the school in the form of a bear. This study discusses the study of character design in its role in a story. The theory used to study this problem is Semiotics theory which will be analyzed about the elements forming the design of the Monokuma character and the roles are shown. This study discusses how the development of the visual world in creating meaning in the mind of the audience.
\end{abstract}

Keywords : anime, character design, Danganronpa, Monokuma, semiotics 


\section{PENDAHULUAN}

Perkembangan kehidupan manusia di era teknologi semakin ditandai dengan adanya kebutuhan untuk selalu terhubung dengan media-media informasi. Akses-akses masyarakat terhadap media baik yang bersifat informatif (portal berita, jurnalistik daring, dan sebagainya) maupun yang bersifat hiburan (Netflix, Hulu, Spotify dan sebagainya) makin tinggi. Keberadaan media-media informasi menjadi terus berkembang dan menjadi bagian dalam aktivitas dan rutinitas masyarakat. Perkembangan media yang terus menerus, membuat masyarakat kini menjadi masyarakat yang termediasi (Ritzer, 2012). Citra audio dan visual yang ditampilkan oleh media-media masa kini menjadi daya tarik sumber informasi sekaligus hiburan di tengah masyarakat.

Keberadaan manga (komik Jepang) dan anime (film kartun animasi Jepang) sudah bukan hal yang asing di Indonesia. Keberadaan kedua media tersebut sudah cukup lama beredar di Indonesia. Beberapa stasiun televisi di Indonesia juga pernah menayangkan anime seperti Doraemon, Sailormoon, Dragonball ataupun Detective Conan dan Naruto. Anime tentu saja adalah media dengan sifat menghibur. Meski berkesan menghibur dan memiliki karakter-karakter visual yang bersifat kekanakan, anime memiliki kompleksitas dalam penetrasi pasarnya. Anime memiliki berbagai macam genre yang disesuaikan dengan cerita dan target penonton. Genre tersebut nantinya akan berkaitan dengan banyak hal mulai dari desain karakter, pewarnaan, visualisasi cerita hingga termasuk ideologi di dalamnya. Perkembangan teknologi informasi membuat masyarakat makin mudah mendapatkan informasi, tetapi menjadi makin sulit juga dipuaskan oleh informasi dari media-media yang ada. Hal inilah yang membuat industri anime terus mengembangkan diri dari tiap elemen penyusun keberadaan anime tersebut.

Beberapa genre anime didesain bagi penonton dengan preferensi tertentu, bukan sekedar ingin menikmati gambar lucu atau warna yang menarik tapi juga alur cerita yang dalam. Keberadaan alur cerita yang kompleks membuat tantangan yang lebih mendalam dalam menyusun cerita pada sebuah anime. Anime pada posisinya di dunia seni, merupakan bagian dari karya audio visual. Penggarapannya pun tidak lepas dari pakem yang ada pada saat penggarapan sebuah karya film pada umumnya.

Kebutuhan penonton terhadap berbagai macam genre pada anime membuat para produser anime menawarkan berbagai macam konsep cerita yang unik dan berkembang ke berbagai macam sisi kehidupan. Tidak sekedar melakukan eksplorasi terhadap kehidupan sehari-hari tetapi juga merambah berbagai sisi. Eksplorasi ini memunculkan variasi bentuk storyline bahkan memiliki kedalaman filosofis dalam proses visualisasi sebuah anime. Salah satu anime yang memiliki keunikan adalah Danganronpa. Danganronpa franchise merupakan multiplatformseries yang berawal dari video game. Pada Desember 2012, majalah Kadokawa Shoten's Newtype mengumumkan bahwa akan ada adaptasi dari seri Danganronpa ke dalam versi anime yang akan disutradarai oleh Seiji Kishi. Anime Danganronpa mulai tayang pada 4 Juli 2013 hingga 26 September 2013 di Jepang sedangkan untuk tayang di Amerika Utara pada November 2015. Cerita yang diangkat berdasarkan cerita pada versi video game yang telah beredar (Trigger 
Happy Havoc and Goodbye Despair). Seri Danganronpa ini dilanjutkan dengan judul Danganronpa 3 : The End of Hope's Peak High School yang terbagi dalam dua timeline berbeda dengan subjudul Side Despair yang memiliki cerita yang merupakan prequel dari original video games dan Side : Future yang merupakan kesimpulan dari grand story yang ada. Kedua seri yang berbentuk anime ini ditayangkan antara Juli hingga September 2016.

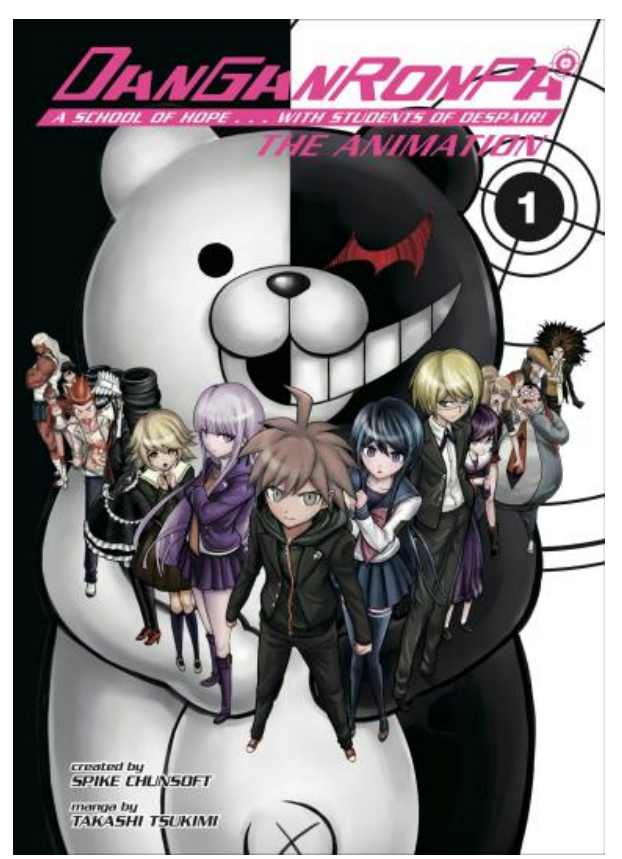

Gambar 1. Cover Anime Danganronpa

[Sumber : www. danganronpawikia.com]

Penelitian ini berfokus pada analisa semiotika terhadap salah satu karakter utama pada anime ini dalam konteks visualisasi dan storyline yang terbentuk dalam anime Danganronpa. Karakter utama pada anime ini yang menjadi kajian adalah Monokuma. Dalam cerita Danganronpa, Monokuma adalah karakter yang muncul sebagai kepala sekolah di Hope's Peak Academy yang menjadi setting utama pada anime ini. Analisis yang akan dilakukan dengan cara membaca tanda-tanda visualisasi yang ada menggunakan analisis semiotika kemudian melakukan pengecekan silang dengan makna cerita yang disampaikan serta filosofi yang muncul pada anime Danganronpa ini.

\section{METODE PENELITIAN}

Penelitian di bidang ilmu komunikasi dapat dibedakan berdasarkan pendekatannya atau berdasarkan falsafah yang mendasari suatu metodologi penelitian. Penelitian ini menggunakan pendekatan kualitatif. Karena dalam penelitian menghubungkan teks tertentu dengan sistem pesan dimana ia beroperasi. Hal ini memberikan konteks intelektual pada isi, yakni mengulas cara-cara beragam unsur teks yang bekerja sama dan berinteraksi dengan pengetahuan kultural untuk menghasilkan makna, maka dari sisi ontologi atau menyangkut asumsi dasar tentang realitas, yaitu "what is the nature of reality". 
Penelitian kualitatif ini menggunakan pendekatan deskriptif kualitatif menggunakan metode studi kritis dengan image based research, yakni meneliti dan mengungkapkan visual image sebagai dasar penelitian. Dalam proses interpretasi, peneliti akan melakukan proses dialektikanya dengan teks sebagai obyek. Artinya peneliti mengasumsikan bahwa realitas merupakan hasil konstruksi mental dari individuindividu pelaku sosial, karenanya realitas itu dipahami secara beragam oleh setiap individu. Adapun langkah-langkah penelitian yang akan dilakukan adalah sebagai berikut:

1) Danganronpa sebagai objek penelitian akan didokumentasikan dan diamati secara seksama.

2) Mengamati dan memilih adegan dari Danganronpa untuk dianalisis menggunakan pendekatan metodologi visual, khususnya pada area site of image itself untuk memperoleh tanda-tanda yang diartikulasikan dalam setiap tampilan tokohnya khususnya dalam konteks penggunaan smartphone. Peneliti bertindak untuk melakukan interpretasi, pemaknaan dan pemahaman terhadap objek visual yang diamati. Dengan kemampuan analisis kritis peneliti membaca dan mengurai makna satu per satu dari komposisi yang membentuk dan melekat pada objek gambar visual yang ada.

3) Penelitian ini menggunakan metodologi visual dimana didalamnya terdapat tiga situs produksi makna, yakni: site (s) of the production of image, site (s) of the image it self dan site (s) of where is it seen by various audiences (Rose, 2003: 30). Penelitian ini menggunakan sudut pandang dari gambar itu sendiri (the site of the image it self), hal ini sangat berhubungan dengan subjek yang aktif (tunggal dan bukan sebagai khalayak) dalam mengintepretasi visual image. The site of the image itself merupakan hal yang esensi dari sebuah representasi suatu teks.

Secara umum langkah penelitian melalui pengamatan/observasi terhadap objek yang diteliti, sebagai berikut:

a. Dokumentasi dan observasi mendalam. Pendokumentasian aktivitas Monokuma dalam seri Danganronpa menggunakan aplikasi capture video dengan setting gambar beresolusi tinggi, agar kualitas gambar tetap baik saat tampilan gambar diperbesar, guna memudahkan proses analisis. Observasi mendalam berarti mengamati secara seksama, meliputi kegiatan pemusatan perhatian objek penelitian dengan menggunakan seluruh alat indera.

b. Kepustakaan atau studi literatur, merupakan teknik pengumpulan data yang berupa buku-buku, ensiklopedia budaya, jurnal ilmiah, majalah, situs-situs internet, artikel dan sebagainya yang berhubungan dengan toipik penulisan, yakni visual culture, cultural studies dan hiperrealitas.

Metode analisis yang digunakan adalah analisis semiotika. Semiotika adalah ilmu yang mempelajari tentang tanda. Tanda-tanda tersebut menyampaikan suatu informasi sehingga bersifat komunikatif. Semiotika berasal dari kata Yunani semeion, yang berarti tanda. Semiotika, sebagaimana dijelaskan oleh Fedinand de Saussure adalah ilmu yang mempelajari peran tanda (sign) sebagai bagian dari kehidupan sosial. Semiotika adalah ilmu yang mempelajari struktur, jenis, tipologi, serta relasi-relasi tanda dalam 
penggunaannya di dalam masyarakat. Tradisi semiotik terdiri atas sekumpulan teori tentang bagaimana tanda-tanda merepresentasikan benda, ide, keadaan, situasi, perasaan dan kondisi di luar tanda-tanda itu sendiri. (Littlejohn, 2009).

Dalam memahami realitas di sekitarnya, manusia tidak mampu lepas dari proses pemaknaan terhadap tanda-tanda yang muncul di sekitarnya. Hal ini dikarenakan menurut Chandler, bahwa realitas manusia dibangun berdasarkan proses produksi dan konsumsi tanda. (Chandler, 2007). Representasi tanda yang muncul dapat dilihat dari berbagai macam penanda mulai dari gelas Starbucks yang dipegang seseorang hingga antrian yang mengular pada peluncuran iPhone seri terbaru. Lebih lanjut, Barthes menuliskan tentang prinsip signification atau penandaan. Signification dapat dipahami sebagai sebuah proses yang berupa tindakan, yang mengikat signifier dan signified, dan yang menghasilkan sebuah tanda. Dalam proses tersebut, dua bagian dari sebuah tanda tergantung satu sama lain dalam arti bahwa signified diungkapkan melalui signifier, dan signifier diungkapkan dengan signified. Misalnya, kata "kucing". Ketika kita mengintegrasikan signifier "kucing" dengan signified "hewan berkaki empat yang mengeong", maka bahasa tanda "kucing" pun muncul. Proses ini disebut sebagai signification atau sebuah sistem signifikasi. (Barthes, 1968)

\section{HASIL DAN PEMBAHASAN}

\subsection{Anime sebagai Media Hiburan}

Anime adalah bagian dari budaya pop Jepang yang sudah menjadi bagian dari masyarakat secara dunia. Umumnya anime memiliki cerita yang sama dengan versi manga atau komiknya. anime dan manga menjadi media yang menjadi komoditas ekspor Jepang ke seluruh dunia selain video games. Anime sebenarnya merupan versi bergerak dari manga yang umumnya terbit terlebih dahulu. Dalam pengertian sempit, manga merujuk pada komik Jepang, tetapi manga pada perkembangannya menjadi fenomena lintas media, yang memiliki konten sangat luas. (Ito, Okabe, \& Tsuji, 2005). Lebih lanjut, Ito menjelaskan bahwa budaya manga menciptakan ekor-ekor baru seperti animasi dari manga tersebut atau anime, video games, figur-figur koleksi, dan berbagai macam media visual lainnya.

Perkembangan teknologi khususnya dalam media-media massa, membuat anime sebagai salah satu bagian dari media yang bergerak (umumnya serial anime ditayangkan di televisi) ikut berkembang juga. Dalam konteks budaya konsumen, perubahan yang tampak adalah adanya komodifikasi dari cerita yang ditawarkan serta desain-desain tokoh yang muncul. Dalam bukunya, The Society of Spectacle, Guy Debord menjelaskan bahwa dalam konsep dan konteks budaya penonton, materi tontonan bukanlah sekedar gambar yang disaksikan tetapi merupakan bentuk relasi sosial antar penonton yang dimediasi oleh tayangan media. Lebih lanjut, Debord menjelaskan bahwa tontonan yang ditayangkan oleh media bukan merupakan "dekorasi" yang berbicara melalui visual dan audio tetapi merupakan jantung dari realitas masyarakat. Dalam berbagai manifestasi seperti iklan, propaganda hingga tontonan hiburan merupakan perlambang dari model kehidupan yang ada. Apa yang ditayangkan seringkali menjadi pembenaran atau 
propaganda sebuah sistem atau tujuan tertentu dari pihak-pihak tertentu. (Debord, 1994)

Dalam konteks Joseph Nye, selain untuk tujuan hiburan, anime merupakan bentuk soft power Jepang dalam menciptakan komoditas berupa visual. Dalam kaitan dengan konsep soft power, anime menawarkan produk yang bersifat leisure dengan tema dan cerita yang sederhana namun menawarkan visual yang dapat dinikmati berbagai khalayak. (Nye, 2004). Sebagai produk seni, anime memiliki sifat menawarkan kesenangan bagi penontonnya. Seni ini yang kemudian menjadi sebuah komoditi sehingga disebut produk. Hal ini dikarenakan sebagai produk seni, anime memberikan kesenangan yang merupakan hasil dari permintaan pasar.

Kebutuhan terhadap tontonan yang artistik ini yang mendorong anime menjadi sebuah komoditas seni. Sebagai komoditas yang bersifat seni, maka anime memiliki subjektivitas dari pengarang atau penciptanya. Subjektivitas ini dapat terlihat dari gaya gambar, pewarnaan, karakter, cerita hingga ideologi yang dibawa sebuah anime. Anime memiliki realm tersendiri bagi penikmatnya. Hal ini karena anime merupakan karya lanjutan dari sebuah manga. Sehingga walaupun cerita yang dibawakan adalah sama, penikmat anime memiliki harapan yang lebih dibanding versi manga. Penggemar atau fans dari karya-karya anime menjadi bagian dalam sebuah lingkaran konsumsi yang dalam masyarakat kapitalisme global atau masyarakat konsumer disebut berada di bawah kekuasaan media massa (Piliang, 2003). Dalam sebuah tampilan media massa, penonton diajak untuk meikmati tontonan dan dalam hal ini, anime yang memiliki sifat menghibur, memiliki kelebihan untuk dapat menarik perhatian lebih kepada penonton. Kemampuan anime dalam menciptakan visual yang menarik dan cerita yang kompleks dapat menjadi jalan untuk dapat meramu tanda-tanda, pengalaman-pengalaman dalam benak penonton dan menciptakan sebuah pemahaman baru.

\subsection{Tinjauan Cerita Danganronpa}

Cerita pada seri Danganronpa berpusat pada kehidupan di Hope's Peak Academy (Kibogame Academy dalam serial bahasa Jepang) dimana setiap tahun ajarannya melakukan seleksi khusus untuk murid-murid tertentu dengan status "Ultimate" (chō$k \bar{o} k \bar{o}-k y \bar{u}$, atau Super High School Level). Status ini diberikan untuk murid-murid dengan talenta-talenta yang berada di atas rata-rata murid pada umumnya. (Eisenbeis, 2013)

Cerita ini dikemas dengan premis yang menarik. Dikisahkan bahwa ada 15 pelajar dengan status "ultimate" tersebut tiba-tiba mendapati bahwa mereka terkunci di gedung sekolah. Dalam kondisi tersebut mereka berkumpul di sebuah ruangan besar dan bertemu dengan kepala sekolah tersebut yang berwujud boneka beruang dengan nama Monokuma. 


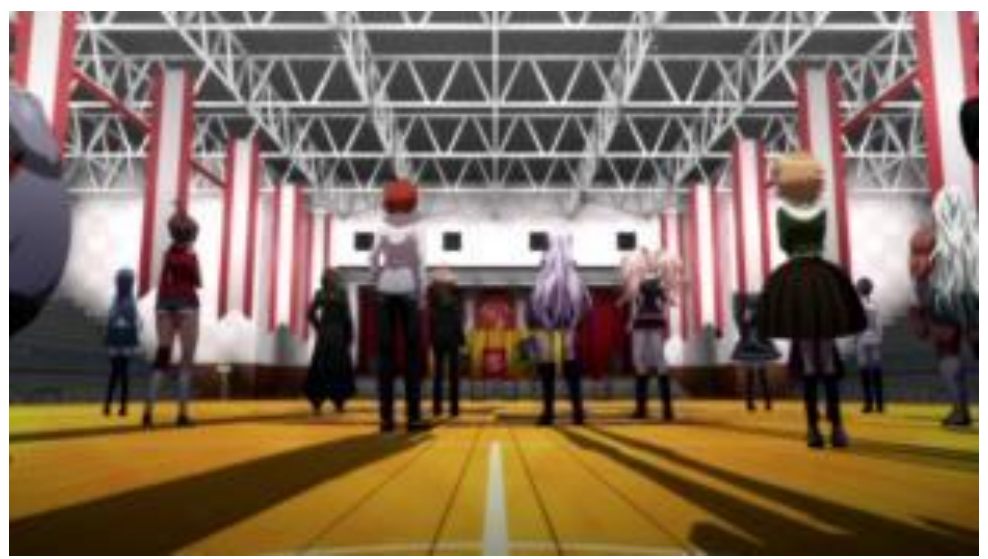

Gambar 2. Suasana ketika 15 pelajar "Ultimate" berkumpul [Sumber : Dokumen penulis]

Kemunculan karakter Monokuma menjadi sentral permasalahan yang terjadi pada anime ini. Para ultimate student ini dapat keluar dari sekolah dengan cara membunuh teman mereka tanpa ketahuan menjadi pelaku pembunuhan atau tidak perlu terjadi pembunuhan namun mereka akan terjebak selamanya di Hope's Peak Academy. Dalam seri Danganronpa dikisahkan apabila terjadi pembunuhan, maka para pelajar diberi waktu untuk mencari pelaku dan kemudian terjadi Trial Class atau pengadilan kelas untuk mencari pelaku. (Eisenbeis, 2013)

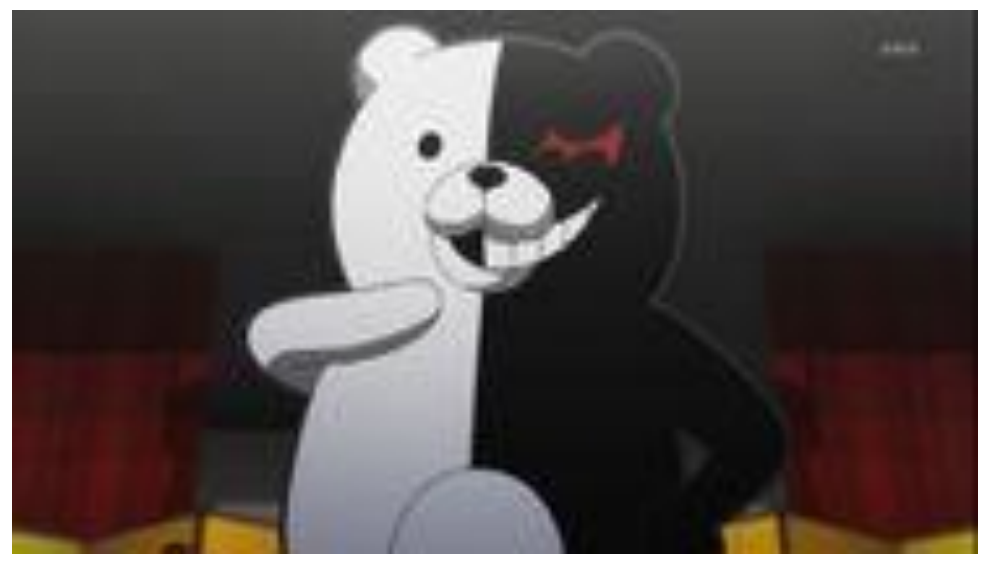

Gambar 3. Karakter Monokuma

[Sumber : Dokumen penulis]

Dalam proses pengadilan kelas tersebut, masing-masing pelajar akan melemparkan pendapat dan argumen mereka untuk menemukan pelaku pembunuhan. Bila ternyata pelaku tersebut memang melakukan pembunuhan maka pelaku tersebut akan menjalani hukuman yang sadis. Dalam konteks cerita ini, Monokuma mengetahui pelaku sebenarnya. 


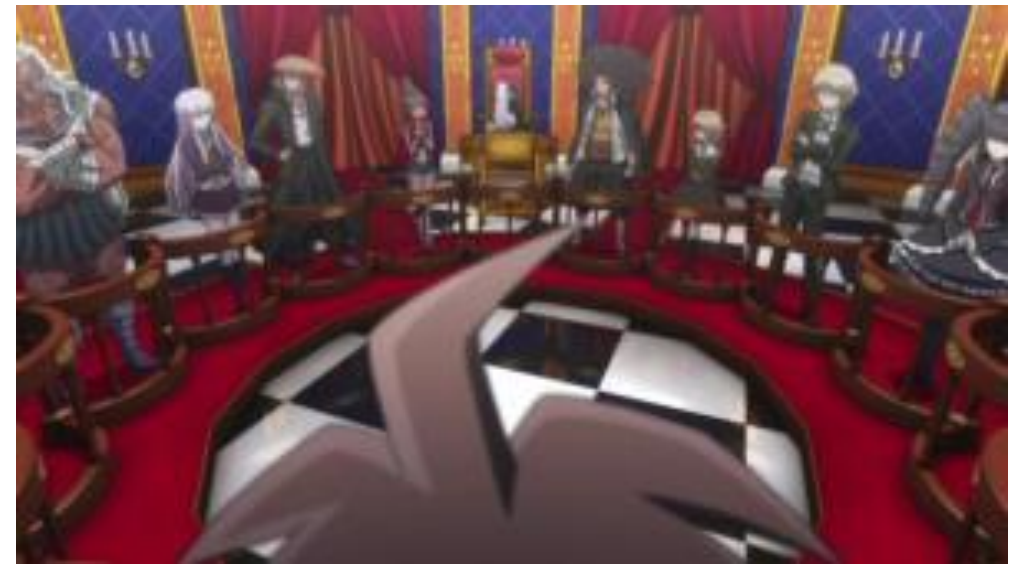

Gambar 4. Pengadilan Kelas pada seri Danganronpa

[Sumber : Dokumen penulis]

Dalam seri Danganronpa pada video games, sebelum terjadi pengadilan kelas, ada waktu yang bisa dimanfaatkan pemain untuk meningkatkan skill karakter maupun mencari informasi mengenai karakter lain yang ada pada cerita.Sedangkan pada versi anime karakter-karakter yang terlibat ini akan diberi waktu terbatas untuk mencari bukti-bukti hingga waktu Class Trials ditentukan.

\subsection{Analisis dan Pembahasan}

\subsubsection{Studi Karakter Monokuma}

Dalam anime Danganronpa, sosok sentral yang muncul adalah karakter Monokuma yang merupakan karakter antagonis. Antagonis dalam konteks anime Danganronpa disini adalah penyebab dari konflik yang menjadi sumber cerita. Untuk dapat melakukan analisis dari karakter ini, maka peneliti melakukan penjabaran terhadap peran yang ditampilkan oleh karakter Monokuma, dialog yang muncul serta ekspresi dan gesture tubuh yang diperagakan.

\subsubsection{Studi Peran Karakter Monokuma}

Dalam anime Danganronpa, karakter Monokuma diceritakan memiliki peran sebagai kepala sekolah dari sekolah elit yang bernama Hope Peak Academy.

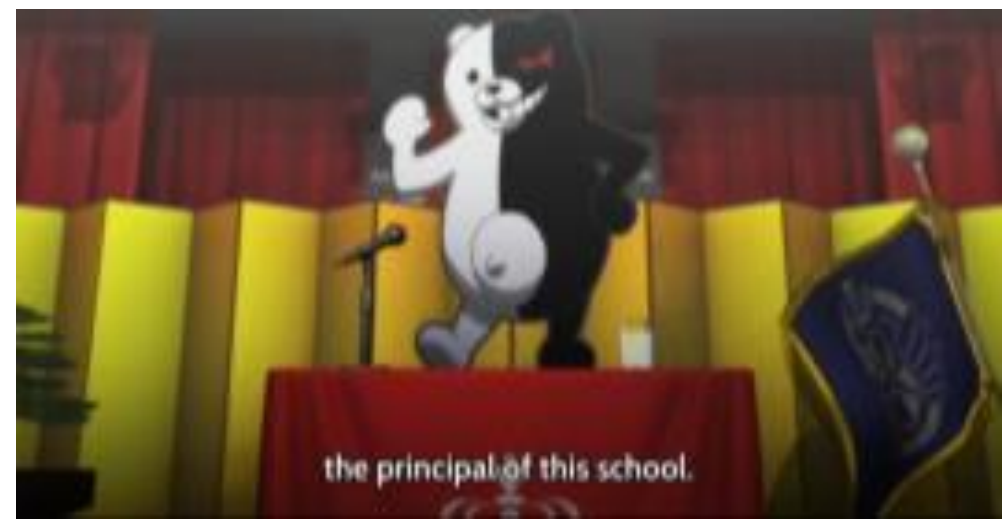

Gambar 5. Kemunculan Monokuma sebagai Kepala Sekolah Hope Peak Academy [Sumber : Dokumen penulis] 
Dalam cerita Danganronpa, Hope Peak Academy merupakan sekolah yang didirikan untuk siswa dengan kemampuan tertentu yang menonjol yang memiliki istilah Ultimate Students. Para siswa yang ada di sekolah ini, diberi tugas oleh Monokuma yang adalah kepala sekolah, untuk saling membunuh dengan cara apapun. Bagi yang berhasil membunuh dengan tidak terdeteksi oleh rekan-rekannya, akan dinyatakan berhasil dan lulus.

Dalam cerita, akan ada pengadilan kelas untuk mencari pelaku sebenarnya. Apabila pelaku tersebut diketahui oleh rekan-rekannya melalui argumentasi dan bukti yang kemudian disahkan oleh Monokum, maka Monokuma akan memberikan hukuman.

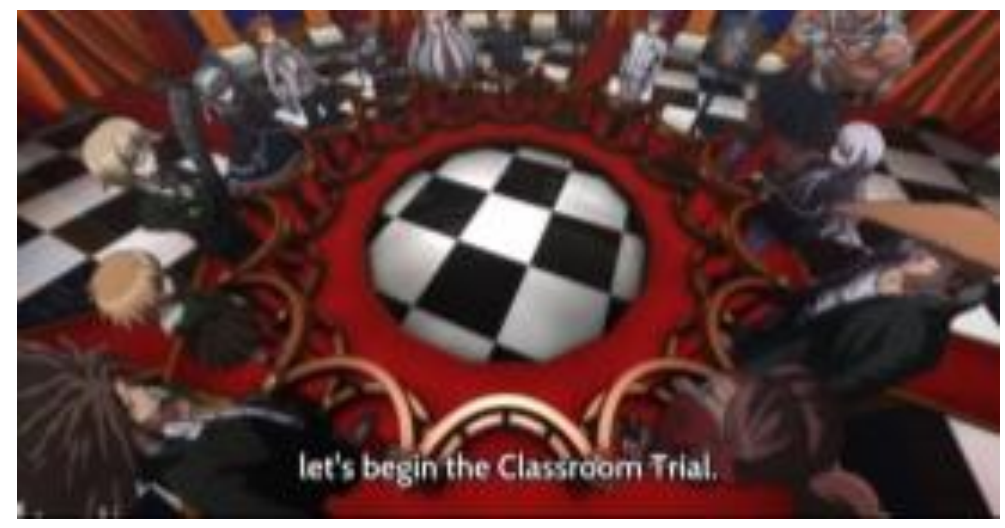

Gambar 6. Proses sidang dalam Danganronpa

[Sumber : Dokumen penulis]

Dalam konteks peran disini, secara denotatif, peran Monokuma adalah kepala sekolah yang berarti dalam konteks bahasa, kepala sekolah merupakan pimpinan administratif tertinggi dalam struktur sebuah sekolah. Dari sisi peran untuk memberikan tugas, reward dan punishment, karakter Monokuma identik dengan konteks pemimpin otoriter yang menggunakan konsep benar dan salah, berhasil dan gagal, reward dan punishment secara individu. Bila ada yang membantah maka hukuman akan berlaku untuk semua siswa. Mengacu pada pemaknaan semiotika Barthes maka, kondisi ini dapat menciptakan analisis bahwa pemaknaan karakter Monokuma dapat digambarkan sebagai sosok ikonik menyerupai beruang tapi berukuran kecil, berwarna hitam putih hendak menegaskan peran memberikan reward dan punishment. Semiotika bahwa warna putih menggambarkan keadaan bersih, suci, kudus dan hitam menggambarkan suram, gelap, kejahatan. Melalui visualisasi desain dan peran Monokuma digambarkan sebagai kepala sekolah tetapi juga hakim kehidupan yang menentukan hidup mati siswa di Hope Peak Academy, sebagai penguasa tertinggi atau bahkan Tuhan.

\subsubsection{Studi Dialog dan Gestur Karakter Monokuma}

Dalam anime Danganronpa, dari dialog-dialog yang dilakukan oleh Monokuma, ada beberapa penggolongan yang bisa dikategorikan untuk dapat dianalisis. Dalam konteks analisa dialog pada anime, maka tidak bisa dipisahkan dari analisa terhadap gestur tubuh saat dialog terjadi. Gestur yang muncul saat ada dialog tertentu dapat menjadi suatu 
simbol terhadap makna kalimat yang terucap. Penggolongan tersebut terbagi dalam 3 konteks :

1. Motivasi

Dalam beberapa dialog yang ada, Monokuma memberikan motivasi terhadap siswasiswa di Hope Peak Academy dengan tujuan untuk melakukan apa yang diperintahkan oleh Monokuma

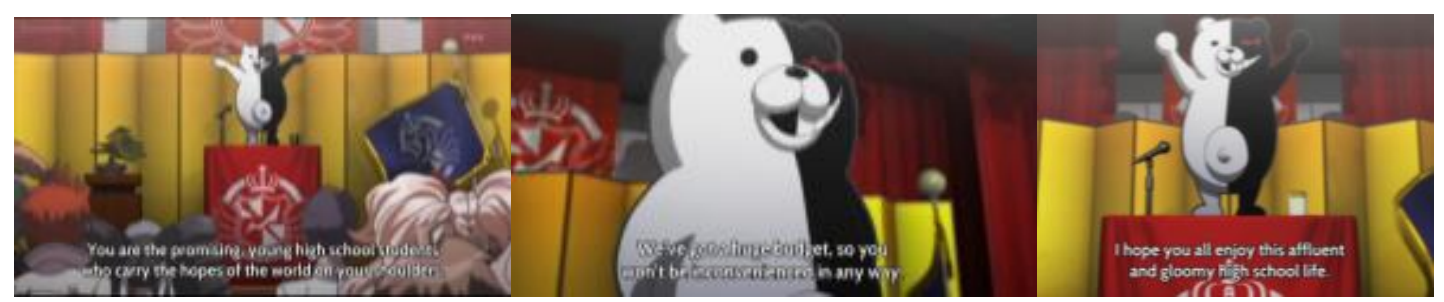

Gambar 7. Contoh ekspresi Monokuma saat memberikan motivasi

[Sumber : Dokumen penulis]

Dalam dialog-dialog ini muncul kata-kata yang bersifat motivasi terhadap para siswa. Motivasi ini berupa hal positif yang memiliki konotasi "baik". Ketika dialog ini terjadi, maka ekspresi dan gesture yang muncul dari sosok Monokuma adalah ekspresi tersenyum bahkan tertawa, terkadang terlihat lucu dan ceria.

2. Ancaman

Selain dialog-dialog dengan nada "positif", Monokuma juga menampilkan dialogdialog dengan nada untuk ancaman, atau kata-kata yang bersifat negatif. Dialogdialog ini tampil dalam beberapa situasi khususnya ketika terkesan ada perlawanan dari siswa Hope Peak Academy.

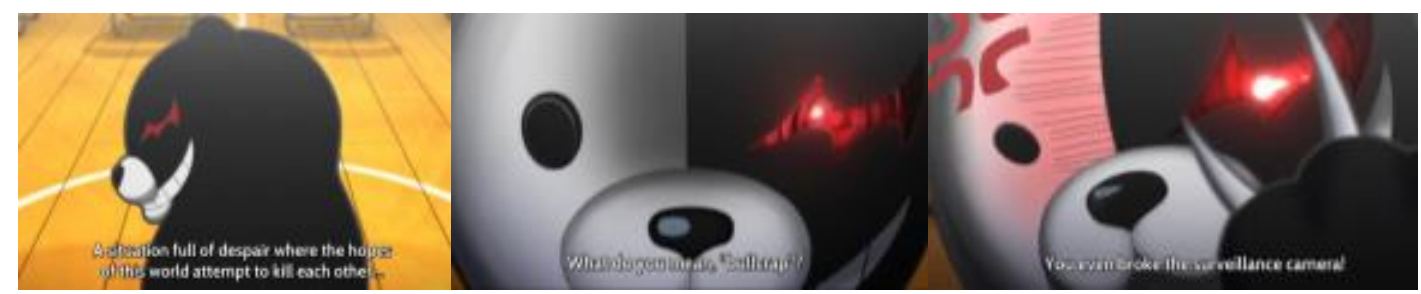

Gambar 8. Contoh ekpresi Monokuma saat memberikan ancaman [Sumber : Dokumen penulis]

Ketika dialog yang muncul berupa ancaman, biasanya muncul ekspresi marah khusunya mata Monokuma yang berwarna merah terlihat menyala. Hal ini ditambah dengan sudut pengambilan kamera yang menjadi close up.

\section{Retorika}

Konteks retorika muncul saat Monokuma melakukan argumentasi terhadap keputusan-keputusan yang diambil dalam pergerakan cerita di Danganronpa. Dialog bersifat retoris ini juga biasanya muncul dalam percakapan saat persidangan kelas untuk memutuskan siapa yang bersalah. Dialog-dialog ini muncul untuk menghindari 
tuduhan tertentu kepada Monokuma, atau ketika persidangan kelas, Monokuma melakukan intervensi dalam proses sidang.

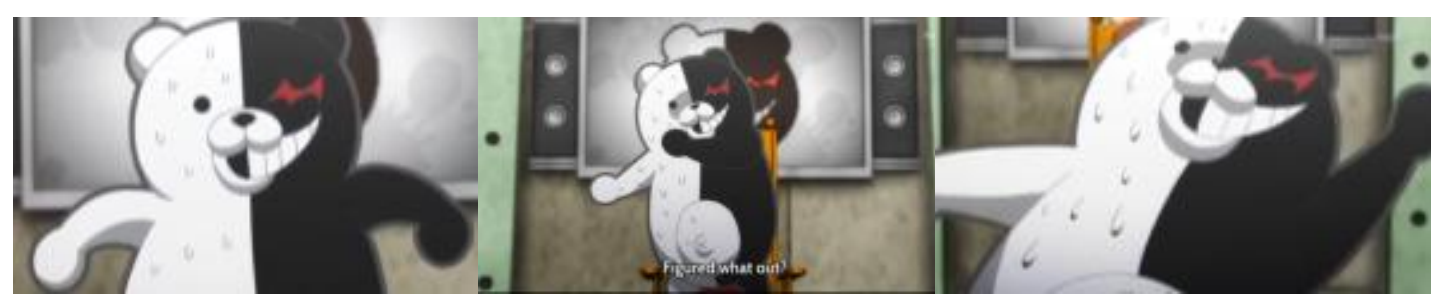

Gambar 9. Contoh ekpresi Monokuma saat kaget atau terkejut

[Sumber : Dokumen penulis]

Dialog saat ada hal-hal yang bersifat retoris, maka ekspresi atau gestur yang ditunjukkan oleh Monokuma seperti muncul ikon air di kepala (seperti keringat) atau terkesan terkejut.

\subsubsection{Analisis Karakter Monokuma}

Berdasarkan studi yang sudah dijabarkan terhadap visualisasi karakter, dialog dan gesture, maka ada beberapa point penting yang menjadi dasar analisis terhadap karakter Monokuma.

1) Karakter Monokuma digambarkan sebagai kepala sekolah. Ini ingin menunjukkan konteks kekuasaan terhadap para siswa di Hope Peak Academy. Konsep kekuasaan ini diperkuat dengan dua kondisi :

a. Ikon karakter Monokuma yang mengambil bentuk dari sosok beruang. Dalam bahasa Jepang, kata "Kuma" memang diterjemahkan sebagai binatang beruang. Berdasarkan fakta yang ada (www.onekindplanet.org), beruang memiliki ciri fisik sebagai berikut yaitu hewan mamalia, karnivora atau pemakan daging, ukuran bervariasi dengan rata-rata hingga mencapai tinggi 2 meter, berat bervariasi dengan rataan $770 \mathrm{~kg}$, habitat berupa gunung, hutan dan beberapa area kutub. Beberapa fakta seputar beruang diantaranya; beruang adalah binatang yang cerdas, memiliki kemampuan navigasi yang lebih baik dari manusia, memori yang kuat, ukuran otak yang besar. Beruang memiliki indra penciuman, penglihatan dan pendengaran yang sangat baik. Indra penglihatan beruang mampu mengidentifikasi buah yang sudah matang. Dari data tersebut, maka ikon karakter Monokuma yang tergambar sebagai sosok kepala sekolah dapat dikatakan sesuai dengan visualisasinya yang berdasar pada bentuk beruang. Konteks akademi menunjukkan kondisi yang berhubungan dengan sekolah yang berhubungan dengan kecerdasan.

b. Dalam realita, beruang digambarkan kuat secara fisik, tetapi di anime ini, karakter Monokuma tidak digambarkan berukuran besar. Tetapi permainan semiotika tentang kekuatan dan kekuasaan tergambar melalui cerita ini dimana Monokuma mampu membuat siswa di sekolah tersebut saling membunuh dan tidak melawan Monokuma secara fisik.

2) Melalui dialog dan gesture, dari analisis melalui tiga penggolongan bahwa sosok Monokuma melakukan tindakan yang bersifat teror. Dengan melakukan ancaman, 
pemberian reward dan punishment menunjukkan keinginan untuk berkuasa. Adanya proses pembunuhan bahkan penghukuman yang dilakukan oleh Monokuma sendiri menunjukkan tentang intimidasi terhadap para siswa disana. Dalam hal ini, kontrol dan hegemoni menjadi agenda bagi karakter Monokuma, dan hal ini ditunjukkan dengan gesture dan dialog yang bersifat ancaman dan intimidasi.

Berdasarkan analisis diatas, dapat disimpulkan bahwa karakter Monokuma, bukan sekedar karakter yang diciptakan tanpa alasan atau sekedar ada bentuk dasar kemudian digambarkan ulang untuk menjadi lebih lucu atau sekedar aneh. Dengan dasar yang jelas, karakter Monokuma disini dapat didefinisikan sebagai figur yang menyimbolkan tentang kekuasaaan dan teror. Dalam karakter Monokuma, tergambar sosok yang bersifat antagonis tapi tidak ditampilkan secara visual dengan tatanan gambar yang menyeramkan.

Dari segi desain, karakter ini menarik karena dengan ukuran yang kecil terlihat seperti mainan, berwarna putih dan hitam dengan komposisi seimbang, menunjukkan bahwa hanya ada ya dan tidak di dunia ini atau hal yang baik dan jahat. Tidak ada toleransi dan hanya ada dua hal tersebut. Selain mata yang berwarna merah serta bentuk seperti kilatan petir yang menyimbolkan ketegasan dan kekuatan, memiliki makna bahwa karakter ini yang memiliki peran menonjol meskipun sebagai karakter antagonis.

\section{KESIMPULAN}

Perkembangan media, membuat konten yang ada dalam media tersebut juga ikut berubah. Hal ini juga dikarenakan perubahan masyarakat terhadap media. Anime yang dulu hanya dianggap sebagai tontonan anak-anak, kini berubah dengan segmentasi yang bermacam-macam. Dalam konteks yang positif, dengan karakter seperti Monokuma, penonton dapat mempelajari tentang teror dan intimidasi. Peran desainer menjadi penting karena tuntutan yang tidak lagi sekedar membuat "desain bagus" tapi desain tersebut mampu memberikan wacana dan wawasan terhadap penonton. Dari sudut pandang berbeda, anime ini memberikan mitos terhadap kepala sekolah dengan konteks kekuasaan. Kekuasaan yang tinggi bisa disalahgunakan dengan menebar ancaman dan teror.

Dalam konteks karakter, seri Danganronpa mampu menampilkan sosok karakter Monokuma sebagai karakter yang kontradiktif. Tata visual yang lucu tapi memiliki karakter antagonis. Hal ini diperkuat dengan dialog dan filosofi yang dipegang oleh karakter tersebut. Dari sudut pandang peneliti, anime walaupun bersifat hiburan memiliki potensi yang luas untuk dapat memberikan pandangan tentang ideologi tertentu bagi penontonnya. Di era masyarakat yang akrab dengan budaya melihat, anime bisa menjadi alternatif untuk menyampaikan pesan-pesan moral maupun kritik terhadap kondisi tertentu. Dalam hal ini, karakter Monokuma yang merupakan kritik terhadap kekuasaan yang tinggi, yang bisa menyebarkan terror dan intimidasi. Perkembangan ini baik untuk direspon oleh desainer-desainer Indonesia bahwa desain bukan sekedar baik tetapi juga memberikan makna dan wawasan. 


\section{DAFTAR PUSTAKA}

Animal : Bear. (n.d.). Retrieved Agustus 20, 2018, from https://onekindplanet.org Barthes, R. (1968). Elements of Semiology. New York.

Chandler, D. (2007). Semiotics : The Basic. London: Routledge.

Danganronpa Wikia. (n.d.). Retrieved Agustus 10, 2018, from http://danganronpa.wikia.com

Debord, G. (1994). The Society of The Spectacle. New York: Zone Books.

Eisenbeis, R. (2013). Danganronpa: The Animation Makes a Mess of a Great Game. Ito, M., Okabe, D., \& Tsuji, I. (2005). Fandom Unbound. London: Yale University Press. Lamerichs, N. (2013). The cultural dynamic of doujinshi and cosplay: Local anime fandom in Japan, USA and Europe. Journal of Reception and Audience Studies, 154-177. Littlejohn, S. W. (2009). Theories of Human Communication. Jakarta: Salemba Humanika. Nye, J. J. (2004). Soft Power: The Means to Success in World Politics. New York: Public Affairs.

Piliang, Y. A. (2003). Hipersemiotika : Tafsir Cultural Studies Atas Matinya Makna. Bandung: Jalasutra.

Ritzer, G. (2012). Teori Sosiologi. Yogyakarta: Pustaka Pelajar. 